\title{
The Phillips Curve and the Missing Disinflation from the Great Recession
}

\author{
By Willem Van Zandweghe
}

lthough inflation has unexpectedly run somewhat below the
Federal Reserve's 2 percent objective during much of the
ongoing economic expansion, the lack of deflation and limited disinflation during the Great Recession of 2007-09 presents a much bigger puzzle for economists. During the recession, unemployment rose to 10 percent, but core inflation declined less than 1.5 percentage points. As a result, some economists have questioned whether the traditional inverse relationship between inflation and unemployment—known as the Phillips curve—still holds.

Understanding the "missing disinflation" from the Great Recession is not just of historic interest. As policymakers at central banks around the world rely on macroeconomic models built around a Phillips curve, the ability of these models to explain the behavior of inflation during the recession and its aftermath is an important test of their usefulness.

Recent research has proposed various explanations for the missing disinflation. One popular model by Del Negro, Giannoni, and Schorfheide (2015) successfully accounted for the stable inflation after the Great Recession and convincingly attributed this stability to monetary policy's anchoring of longer-term inflation expectations. However, this model also predicted stable unit labor costs during the Great Recession, a time when labor costs declined. A model that can explain both stable inflation and the cyclical decline in unit labor costs might provide a more complete account of the missing disinflation.

Willem Van Zandweghe is an assistant vice president and economist at the Federal Reserve Bank of Kansas City. This article is on the bank's website at www.KansasCityFed.org 
In this article, I estimate a Phillips curve model that better reflects microdata on consumer prices than the model of Del Negro, Giannoni, and Schorfheide (2015). I find that the estimated model predicts stable inflation with a decline in unit labor costs during the recession, in line with observed patterns. In particular, the model assumes firms adjust their prices infrequently and face a positive trend inflation rate, which leads firms to make more forward-looking decisions when they adjust prices. The central role of expectations allows the estimated model to reconcile the observations of stable inflation and a decline in unit labor costs during the recession. Thus, the analysis supports the view of Del Negro, Giannoni, and Schorfheide (2015) that inflation expectations shaped by monetary policy played an important role in preventing a large disinflation in the wake of the Great Recession. Moreover, the model's ability to account for the observed paths of inflation and unit labor costs suggests that Phillips curve models remain useful tools for central banks.

Section I discusses the evolution of inflation and unit labor costs during the Great Recession and its aftermath and reviews previous research on the missing disinflation. Section II presents the Phillips curve model and the econometric methodology for estimating it. Section III demonstrates that the estimated model predicts stable inflation with a decline in unit labor costs during the recession.

\section{Inflation and Economic Activity in the Great Recession}

The relationship between inflation and economic activity is welldocumented and central to monetary policy. Phillips (1958) and Solow and Samuelson (1960) first documented a negative relationship between inflation and unemployment. Friedman (1968) and Phelps (1968) proposed that inflation is related to inflation expectations as well as economic activity. Research assuming those inflation expectations can be proxied by past inflation underpins the traditional, accelerationist Phillips curve, which predicts that inflation will continue to fall as long as the unemployment rate is above its natural rate. As Ball and Mazumder (2011) show, an accelerationist Phillips curve counterfactually predicts a period of deflation during and after the Great Recession. 
The Great Recession did not leave a clear imprint on inflation, in seeming contradiction with the historical relationship between inflation and economic slack. Panel A of Chart 1 shows the output gap estimated by the Congressional Budget Office (CBO), which measures slack economic activity as the percentage deviation of gross domestic product from its potential level. At the end of 2008, the financial crisis led to a sharp drop in the output gap, which took about a decade to close. But inflation did not respond in kind. Panel B shows that inflation, as measured by the year-over-year inflation rate of the core personal consumption expenditures (PCE) price index, softened only modestly and briefly. In contrast with the relative stability of inflation during and after the Great Recession, inflation in earlier business cycles tended to fall during and after recessions and rise during expansions, although this cyclicality is partly obscured by the long-term rise and fall of inflation in the 1970s and 1980s. ${ }^{1}$

Recent research explains the dynamics of inflation after the last recession using models based on a modern version of the Phillips curve. $^{2}$ This model framework, which is known as the New Keynesian Phillips curve (NKPC), is based on optimizing firm behavior and relates inflation to production costs, inflation expectations, and sometimes other factors (see Galí and Gertler 1999; Woodford 2003). The NKPC differs from the accelerationist Phillips curve in two important ways. First, expectations are not predetermined but are forward-looking. Whereas the accelerationist Phillips curve assumes past inflation proxies for inflation expectations, the NKPC is based on explicit assumptions of how economic agents form expectations about the future (usually agents are assumed to form rational expectations). Second, inflation is directly connected to the real marginal cost of production rather than economic activity. Although the marginal cost of production is determined by economic activity in such models - as wages are determined by labor market activity-economic activity only matters for inflation insofar it affects the real marginal cost. Intuitively, a higher marginal cost of production raises inflation because it leads firms to raise their prices to preserve their profit margins.

The marginal cost of production, as measured by real unit labor costs, declined during the recession. Panel $\mathrm{C}$ of Chart 1 shows real 


\section{Chart 1}

\section{Inflation and Real Activity}

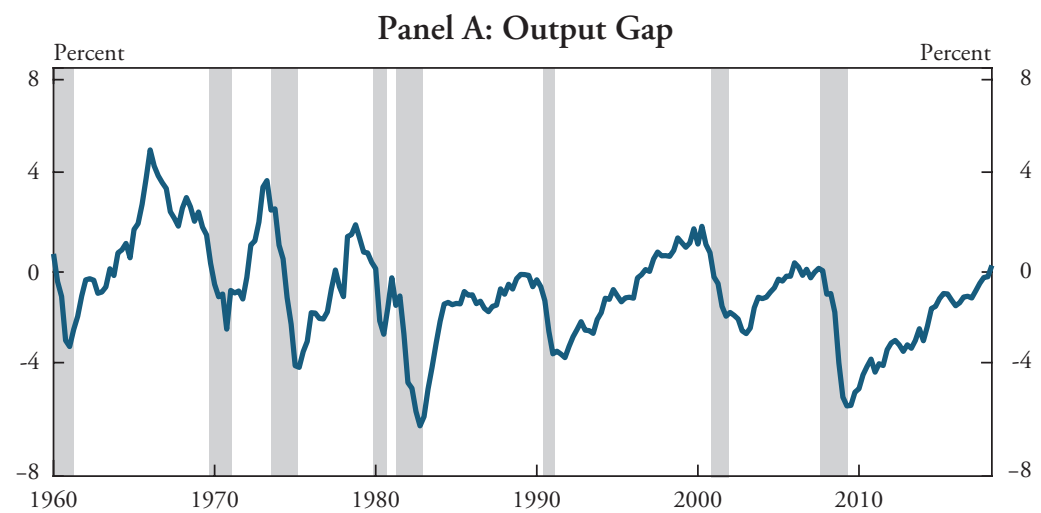

Panel B: Inflation Rate

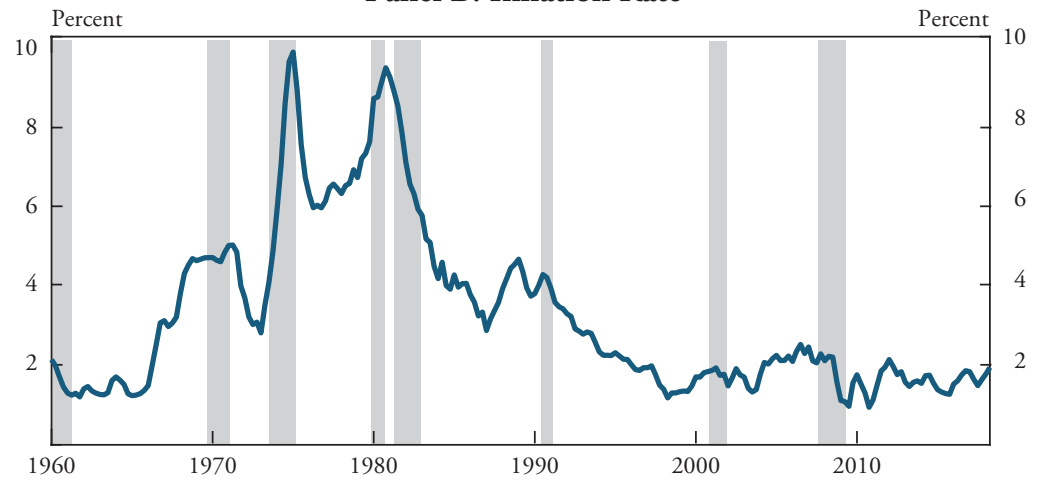

Panel C: Real Unit Labor Cost (Log Deviation from Trend)

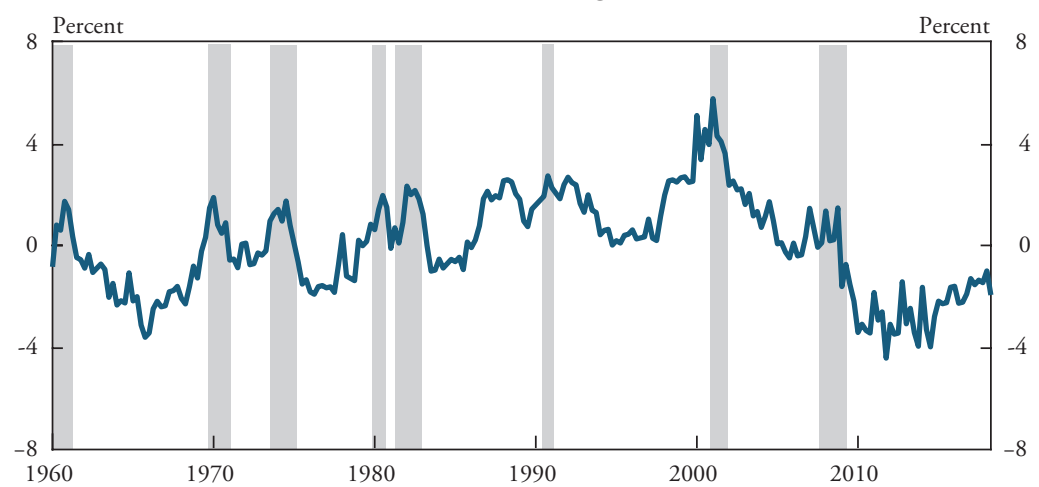

Notes: Gray bars denote National Bureau of Economic Research (NBER)-defined recessions. Panel A shows the Congressional Budget Office's output gap. Panel B shows the year-over-year percentage increase in the core PCE price index. Real unit labor cost is measured by the labor share of income in the nonfarm business sector. Panel C shows the residual of a regression of the logarithm of the labor share on a constant and a time trend for the sample period from 1960:Q1 to 2018:Q2.

Sources: Bureau of Economic Analysis, Bureau of Labor Statistics, NBER, and Congressional Budget Office. All data sources accessed through Haver Analytics. 
unit labor costs - that is, the ratio of real wages to labor productivity_-in the nonfarm business sector in logarithms and as a deviation from its linear trend. Under basic assumptions about the production technology, real unit labor costs are a proxy for firms' real marginal cost of production. Like the output gap, real unit labor costs declined sharply at the end of 2008 and recovered very slowly. Indeed, they remained below trend in the second quarter of $2018 .{ }^{3}$

A growing body of research proposes explanations for the missing disinflation that broadly fall into one of two groups. The first group points to temporary or structural factors that are not directly related to monetary policy. For example, Coibion and Gorodnichenko (2015) point to the temporary surge in oil prices, which reached a record high in mid-2008. They argue that high energy prices raised short-term inflation expectations, putting upward pressure on inflation that offset the downward pull from slack economic activity. Another temporary factor was financial market stress, which surged during the financial crisis in 2008, raising borrowing costs and curtailing access to credit for some firms. Gilchrist, Schoenle, Sim, and Zakrajšek (2017) show that firms with ample liquidity lowered prices in 2008 as would be expected in a recession, while those with limited liquidity raised prices to avoid costly external financing. ${ }^{4}$ Consistently, Christiano, Eichenbaum, and Trabandt (2015) argue that elevated interest rate spreads during the financial crisis put upward pressure on inflation. ${ }^{5}$

Structural factors cited as explanations for the missing disinflation include fiscal policy uncertainty in a policy regime of near-zero short-term interest rates and large fiscal deficits, downward rigidity in nominal wages that prevented the real marginal cost of production and thus inflation from falling, and nonlinearity in the Phillips curve leading the relationship between inflation and economic activity to differ depending on whether economic conditions are slack or tight (see, respectively, Bianchi and Melosi 2017; Mineyama 2018; Doser, Nunes, Rao, and Sheremirov 2018). ${ }^{6}$

The second group of explanations emphasizes the stability of longer-term inflation expectations and the role of monetary policy in preventing a large disinflation. Bernanke (2010) assessed that "falling into deflation is not a significant risk for the United States 
at this time, but that is true in part because the public understands that the Federal Reserve will be vigilant and proactive in addressing significant further disinflation."

Del Negro, Giannoni, and Schorfheide (2015) provide formal support for the view that monetary policy, through its effect on longer-term expectations, played an important role in keeping inflation stable. Inflation according to the NKPC depends on current economic conditions - in particular, the current real marginal cost of production - and expectations of future inflation, which depend on expected future real marginal costs. The authors find that although the real marginal cost of production declined during the Great Recession, firms expected real marginal costs would recover in the future under appropriately expansionary monetary policy. Thus, inflation expectations remained stable and prevented a large decline in actual inflation. The authors estimate their model and obtain a small estimate for the slope of the Phillips curve, which is important for their explanation of why inflation remained stable. Indeed, they demonstrate using their estimated model that a smaller slope of the Phillips curve implies monetary policy has greater influence on expected future real marginal costs and thereby on inflation. ${ }^{8}$

However, Del Negro, Giannoni, and Schorfheide (2015) find that their estimated model understates the observed drop in real marginal costs. As the marginal cost is a key driver of inflation in the NKPC, explaining both the stable inflation and the drop in the real marginal cost appears challenging. Nevertheless, a model that can account for the evolution of both variables - the observed stability of inflation and the decline in the real marginal cost-may provide a more compelling explanation for the missing disinflation.

To that end, I estimate a Phillips curve model that deviates in one key respect from those used in most previous research, including Del Negro, Giannoni, and Schorfheide (2015). A standard assumption in research based on the NKPC is that some firms set their prices optimally while others index their prices to the past or the trend inflation rate. The model I use instead assumes that firms either set their prices optimally or do not change their prices at all. This assumption is consistent with evidence on price changes from the microdata for the consumer price index, which indicate that individual prices change infrequently. 
A firm with a fixed nominal output price will see inflation erode its real revenue, which is not the case if a firm can index its price to inflation. Therefore, if the trend inflation rate is positive, firms that are not able to continually adjust their prices will take more forward-looking decisions when they have the opportunity to adjust their prices. As a result, inflation expectations may play an even more important role for inflation dynamics in models that do not assume price indexation, while smooth dynamics of real marginal costs may play a smaller role.

\section{Estimating Phillips Curve Models}

To assess the role of firms' price-setting behavior in accounting for the behavior of inflation and unit labor costs, I estimate two NKPCs. The first, a standard NKPC, features price indexation to past inflation. The second, known as a generalized NKPC (GNKPC), has no price indexation. ${ }^{9}$ Both models relate inflation to the real marginal cost of production, inflation expectations, and other variables. The models are derived from firms' profit maximization in the face of rigidity in nominal prices, which limits how often firms can expect to reset prices to their optimal level. The standard NKPC relates inflation to the real marginal cost of production, expected future inflation, and past inflation as follows:

$$
\pi_{t}=\kappa m c_{t}+\frac{\beta}{1+\beta} E_{t} \pi_{t+1}+\frac{1}{1+\beta} \pi_{t-1},
$$

where $\pi_{t}$ and $m c_{t}$ denote inflation and the real marginal cost, respectively, in period $t$, and $\kappa$ denotes the slope of the Phillips curve and is a function of structural parameters including households' subjective time discount factor, $\beta$, and the degree of price rigidity, $\alpha_{p}$.

The GNKPC is given by:

$$
\pi_{t}=\kappa_{1} m c_{t}+\kappa_{2} \Delta y_{t}+\lambda \sum_{i=1}^{\infty}\left(\rho_{d}\right)^{i-1} \pi_{t-i}+B E_{t} \pi_{t+1}+\gamma\left(\varphi_{t}+\psi_{t}\right),
$$

where inflation is related to the real marginal cost, output growth $(\Delta y)$, past inflation, expected future inflation, and two additional forward-looking variables denoted by $\varphi_{t}$ and $\psi_{t}$ that capture expectations of future inflation, real marginal costs, and output growth over a long horizon. ${ }^{10}$ Here, too, the coefficients $\kappa_{1}, \kappa_{2}, \lambda, \rho_{d} B$, and $\gamma$ are functions of structural parameters in the model. 
In addition, each model includes equations to describe the behavior of households, which make decisions about how much to work, consume, and save, as well as the behavior of the central bank, which sets the short term interest rate according to a simple interest rate rule. Appendix A provides these equations along with a more detailed description of each model.

The dynamic relationships between the variables of each model are determined by the values of the model's structural parameters. For instance, the slope of the Phillips curve $\left(\kappa\right.$ or $\kappa_{1}$ ) affects the responsiveness of inflation to changes in the real marginal cost. The values of the structural parameters determine how well the model can describe the empirical relationships of key macroeconomic variables for the U.S. economy and are estimated to give the model empirical credibility.

The estimation methodology consists of two steps. In the first step, I estimate the empirical relationships between key macroeconomic variables using a structural vector autoregression (VAR), which captures how the variables respond over time to a surprise change in the stance of monetary policy. Specifically, I estimate a structural VAR on the inflation rate, a measure of the output gap, and the federal funds rate for the period from 1955:Q1 to 2008:Q4, which was the quarter with the most severe contraction in output during the last recession. The data are series typically used in the estimation of a structural VAR with monetary policy shocks and are different from the series displayed in Chart $1 .{ }^{11}$ By ending the sample in 2008:Q4, the estimated Phillips curve models will fit the empirical dynamics of the macroeconomic variables until the recession. Estimating the model on pre-recession data allows me to compare the model's out-of-sample predictions to the actual post-recession data. Similar paths would indicate the empirical dynamics of the macroeconomic variables have not changed.

The dashed lines in Chart 2 display the empirical responses of the federal funds rate, the inflation rate, and the output gap-the three variables in the VAR - to a one standard deviation surprise cut in the federal funds rate. The federal funds rate drops on impact, inflation ticks down initially before rising gradually, and the output gap rises temporarily after a few quarters. 
Chart 2

Empirical Impulse Responses to an Expansionary Monetary Policy Shock
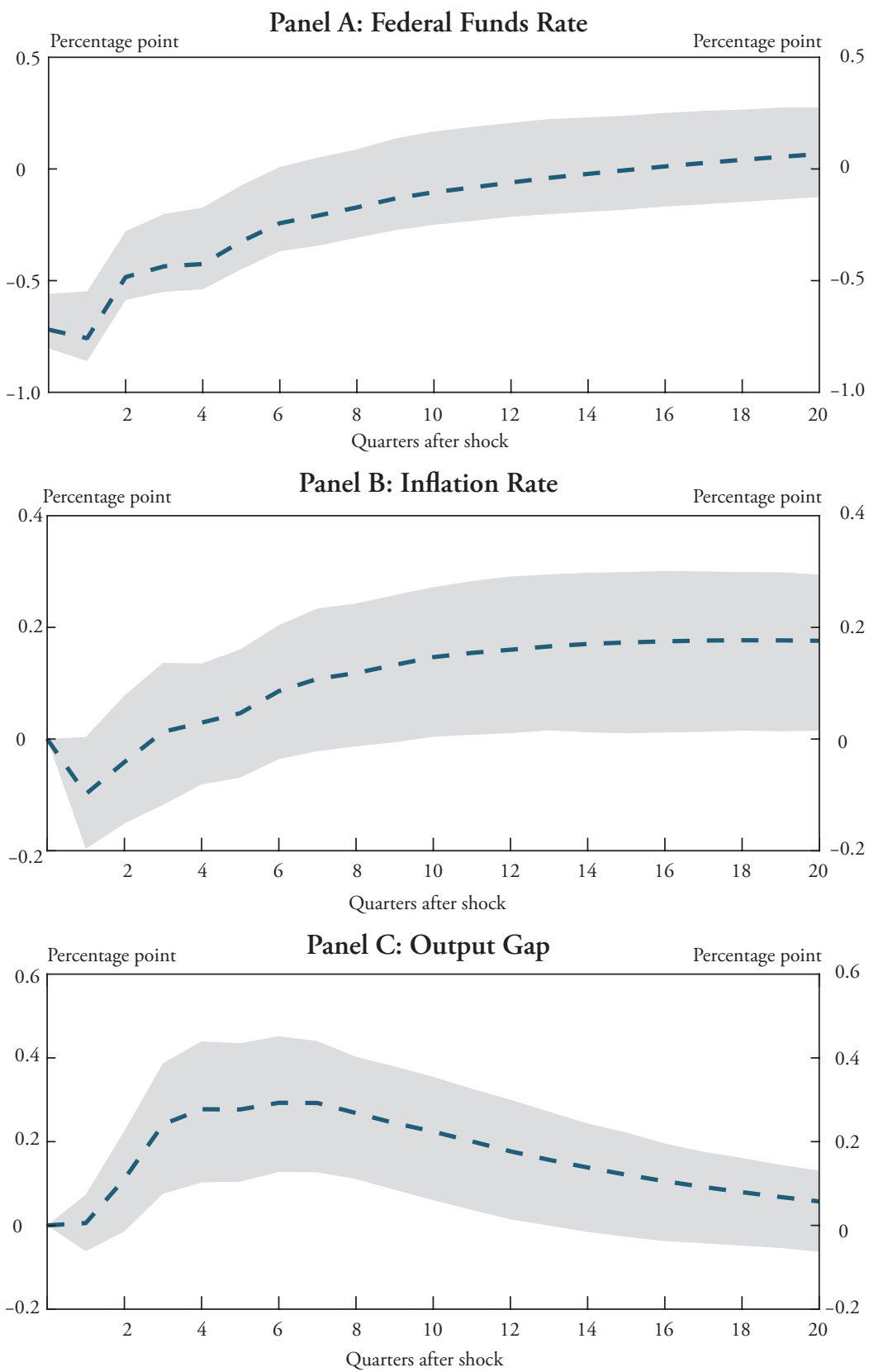

Notes: Dashed lines are impulse responses to a one standard deviation negative monetary policy shock from the structural VAR. Gray bands are 90 percent confidence intervals obtained from 1,000 bootstrap replications. Sources: Bureau of Economic Analysis and Board of Governors of the Federal Reserve System. All data sources accessed through Haver Analytics. 
In the second step, I estimate the parameters of each Phillips curve model by selecting the parameter values that jointly minimize the distance between the empirical impulse responses from the VAR, displayed in Chart 2, and their counterparts generated by a monetary policy shock in the Phillips curve model. More formally, the estimation method entails finding the vector of model parameters, $x$, that minimizes the product $(G(X)-\hat{G})^{\prime} W(G(x)-\hat{G})$, where $G(x)$ and $\hat{G}$ denote, respectively, the stacked impulse response functions of 20 quarters obtained from the Phillips curve model and from the VAR model (excluding the initial quarter), and $W$ is a weighting matrix. ${ }^{12}$ Estimation results for each model are reported in Appendix B.

\section{Accounting for the Missing Disinflation}

To evaluate the estimated NKPC models' predictions for inflation and the real marginal cost, I use the models to simulate the effects of a sudden, large decline in the output gap akin to the observed decline during the last recession.

\section{Model with price indexation}

Chart 3 compares the dynamics of the output gap, inflation, and real unit labor costs (the measure of the real marginal cost) predicted by the estimated model with price indexation to their evolution in the U.S. data since 2008. The blue lines in Panels A through C repeat the data from Chart 1 -that is, the CBO's estimate of the output gap, the year-over-year PCE inflation rate, and real unit labor costs as a deviation from their long-run trend. The green lines show the responses of the same variables in the model to a 6.6 percent decline in the output gap, which equals the decline in the CBO's measure in 2008:Q4. ${ }^{13}$

While the model with price indexation does not capture the highfrequency movements in the U.S. data, it successfully traces the slow recovery in the output gap, which does not close fully until 2018 (Panel A). The model also successfully predicts a stable inflation rate in the face of the deep recession. Panel B shows that inflation in the model temporarily slows to about 1 percent and returns to 2 percent by $2014 .{ }^{14}$ However, Panel $\mathrm{C}$ shows that the model-predicted trajectory for the real marginal cost differs significantly from the observed data. Specifically, the model predicts a modest decline in the real marginal cost of 
Chart 3

Actual and Predicted Inflation and Unit Labor Cost in the Model with Price Indexation

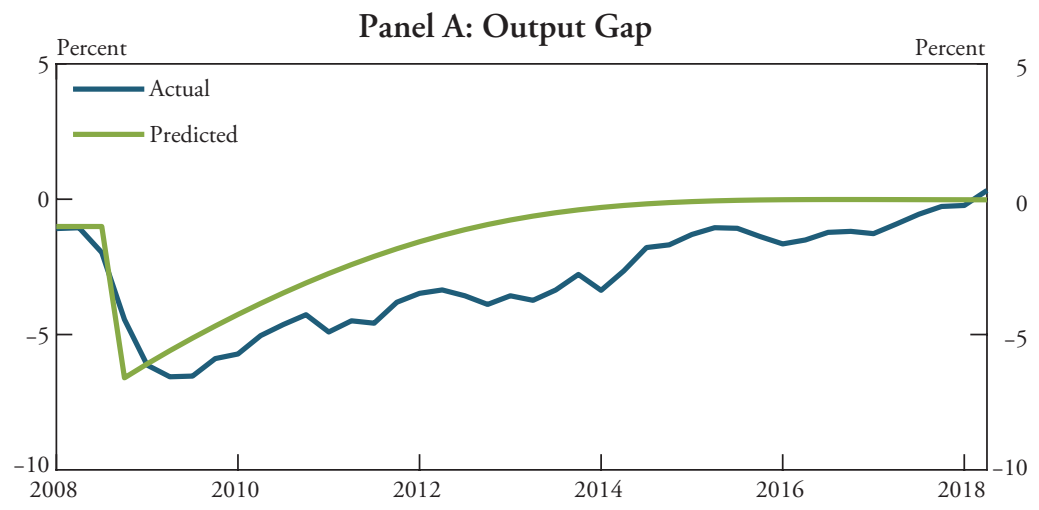

Panel B: Inflation Rate
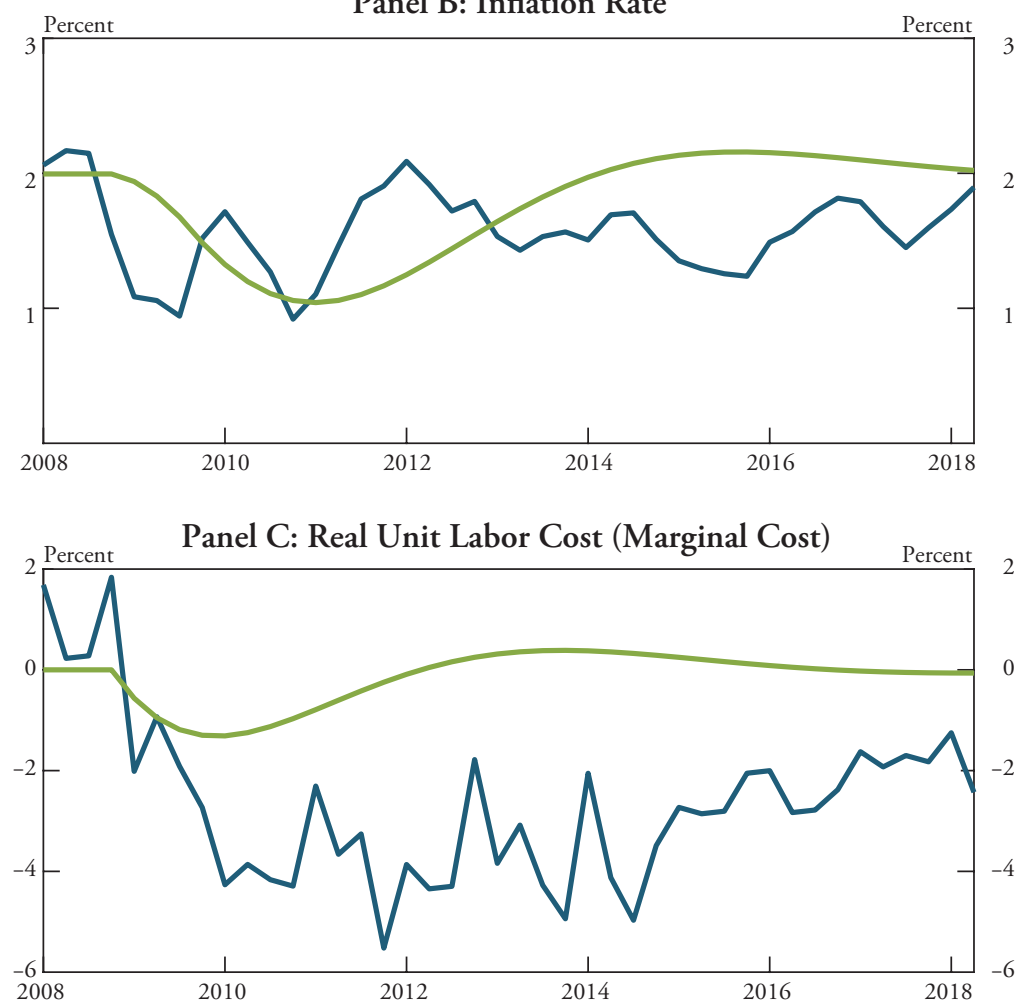

Sources: Bureau of Economic Analysis, Bureau of Labor Statistics, and Congressional Budget Office. All data sources accessed through Haver Analytics. 
1.3 percent below trend at its trough before returning to trend by 2012, while the actual data show real unit labor costs declined about 4 percent below trend before gradually rising by 2014 . The model's prediction of both stable inflation and a stable real marginal cost is consistent with the finding of Del Negro, Giannoni, and Schorfheide (2015).

\section{Model without indexation}

Chart 4, analogous to Chart 3, shows the predictions of the NKPC model without indexation. This model assumes that a fraction of firms keeps their prices unchanged each period, which is consistent with the microdata on consumer prices. Once again, the model successfully traces the gradual closing of the output gap after its assumed drop of 6.6 percent in 2008:Q4 (Panel A). The model also successfully predicts stable inflation in the face of the deep output gap (Panel B). Inflation slows to 0.4 percent in the model, which is lower than in the model with price indexation. However, the model without indexation better reflects inflation's gradual recovery. Specifically, the model shows inflation does not return to 2 percent until 2016, two years later than the model with price indexation - and closer to the actual core inflation rate, which remained below 2 percent during this period. Neither model predicts a period of deflation.

Comparing the models' cumulative prediction errors for inflation (not shown) demonstrates that the model without indexation performs better over a longer horizon. Although the cumulative prediction error for inflation in the model without indexation is larger than in the model with price indexation from 2008:Q4 to 2014:Q4, it is smaller when the prediction is extended from 2008:Q4 to 2016:Q4. Specifically, the cumulative prediction error for the model without indexation is -5.4 percent for the 2008:Q4-2016:Q4 period, indicating the model underpredicts the price level by 5.4 percent by the end of 2016 . In contrast, the model with price indexation overpredicts the price level by 6.4 percent by the end of 2016 .

The main difference between the two models is their ability to capture the evolution of real unit labor costs. The model without indexation shows that the real marginal cost drops about 4 percent below trend by 2010, similar to the data for real unit labor costs. The model then predicts the real marginal cost recovers gradually to its trend level 
Chart 4

Actual and Predicted Inflation and Unit Labor Cost in the Model without Indexation
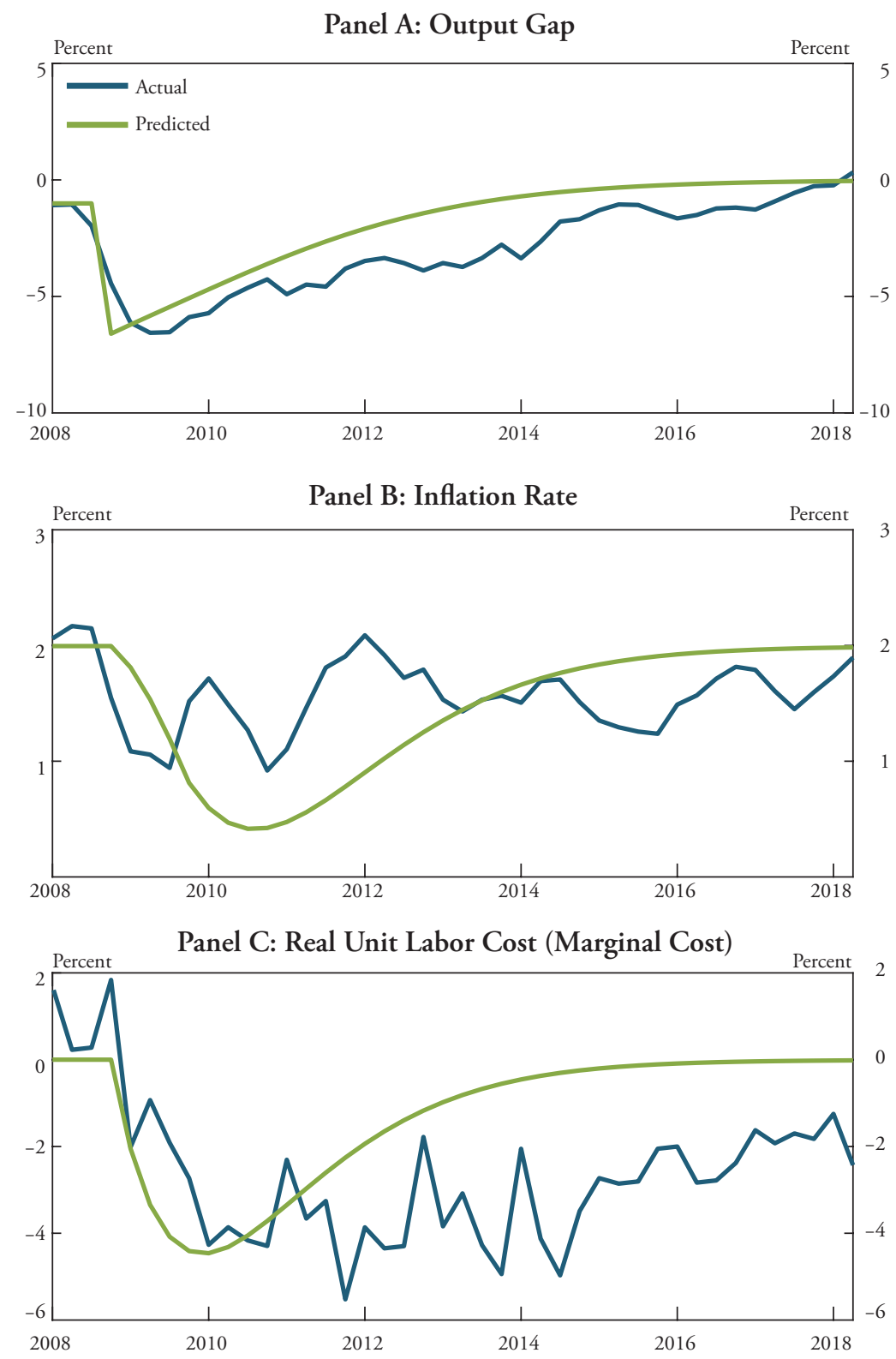

Sources: Bureau of Economic Analysis, Bureau of Labor Statistics, and Congressional Budget Office. All data sources accessed through Haver Analytics. 
by 2014 . Although the recovery is slower than in the model with price indexation, it is still faster than in the U.S. data, where the detrended real unit labor costs remained below trend in 2018.

To further quantify the performance of the two models, I compare their root mean square errors (RMSE), a measure of how far the model predictions differ from observed values. The RMSE of predicted inflation through 2016:Q4 is somewhat smaller for the model with price indexation (0.548) than the model without indexation (0.636), implying the model with price indexation generates a more accurate inflation forecast. However, the RMSE of predicted real unit labor costs is substantially smaller for the model without indexation (2.417) than for the model with price indexation (3.277), implying the model without indexation generates a more accurate forecast for real unit labor costs. ${ }^{15}$ Intuitively, as price-adjusting firms are more forward-looking when they cannot index prices, inflation dynamics are determined to a greater extent by expectations and to a lesser extent by smooth real marginal costs. More precisely, whereas inflation in the NKPC is determined solely by the current and discounted expected future real marginal costs, inflation in the GNKPC is also determined by the current and expected future values of other variables, as shown in Appendix A. As inflation is less tightly linked to current and expected future real marginal costs in the model without indexation, this model can reconcile the observations of stable inflation and a decline in real unit labor costs during the last recession.

\section{Conclusion}

This article provides new evidence supporting the view previously formalized by Del Negro, Giannoni, and Schorfheide (2015) that stable inflation expectations prevented a sharp disinflation during the Great Recession despite the deep output gap and associated weak real unit labor costs. Using a Phillips curve model that better reflects microdata on consumer prices, I find that the estimated model predicts stable inflation with a decline in real unit labor costs during the recession, in line with the observed patterns. The evidence supports the view that inflation expectations and monetary policy were important in preventing a large disinflation. My results have two reassuring implications for monetary policy makers. First, the model's ability to account for the 
observed paths of inflation and real unit labor costs suggests that Phillips curve models remain useful tools for central bankers. Second, the evidence suggests that inflation expectations remained anchored in the face of a deep recession, which attests to the credibility of the Federal Reserve's inflation objective. 


\section{Appendix A}

\section{New Keynesian Model Descriptions}

Both New Keynesian models consist of a representative household, a representative composite-good producer, a continuum of firms, and a monetary authority. The monetary authority follows a Taylor type interest rate rule of the form:

$$
i_{t}=\left(1-\rho_{1}-\rho_{2}\right)\left[\varphi_{\pi} \pi_{t}+\varphi_{y} y_{t}+\varphi_{d y} \Delta y_{t}\right]+\rho_{1} i_{t-1}+\rho_{2} i_{t-2}+u_{t},
$$

where $i_{t}$ denotes the short-term interest rate, $\pi_{t}$ is the inflation rate, $y_{t}$ denotes the output level, $\Delta y_{t}$ denotes output growth, and $u_{t}$ is a white noise monetary policy shock. All variables are expressed as log deviations from their steady-state values and subscripts denote time periods.

In each model, the household decides how much to consume, how much to save in one-period bonds, and how much labor to supply. Household preferences are characterized by external habit formation for consumption $(b)$ and labor supply elasticity $\left(1 / \sigma_{n}\right)$. Labor services are individually differentiated and subject to Calvo staggered wage setting, with a demand elasticity for individual labor services denoted by $\theta_{w}$ and a fraction of wages that remains unchanged each period denoted by $\alpha_{w}$. The households' consumption Euler equation is:

$$
y_{t}=\frac{1}{1+b} E_{t} y_{t+1}+\frac{b}{1+b} y_{t-1}-\left(i_{t}-E_{t} \pi_{t+1}\right),
$$

where $E_{t}$ is the rational-expectations operator conditional on time- $t$ information.

Firms use a labor-only technology to produce differentiated goods and are subject to Calvo price rigidity, where $\alpha_{p}$ is the fraction of prices that is either adjusted by indexation or unchanged each period. The composite-good producer uses an aggregator with variable elasticity of demand as in Kimball (1995), in which two parameters, $\theta_{p}$ and $\varepsilon$, determine the shape of the demand curves.

The two models are distinguished by their assumptions about the behavior of firms unable to optimize their products' prices. In the model with price indexation, these firms are assumed to index their prices to the past inflation rate, as is common in research using 
New Keynesian models. The resulting NKPC is given by equation (1) in the text. In the model without indexation, these firms are assumed to leave their prices unchanged, leading the model's dynamics to depend on the trend inflation rate. ${ }^{16}$ The resulting Phillips curve, known as the generalized NKPC (GNKPC) is given by:

$$
\pi_{t}=\beta E_{t} \pi_{t+1}+\lambda_{1} m c_{t}+\lambda_{2} \Delta y_{t}+a_{\pi} d_{t}+\beta E_{t} d_{t+1}+d_{t-1}+\varphi_{t}+\psi_{t} .
$$

Output growth appears in the case of habit formation (that is, $b>0$ ). The variables $\varphi_{t}$ and $\psi_{t}$ are auxiliary variables that capture expectations of future variables, as shown by their recursive formulation:

$$
\begin{gathered}
\varphi_{t}=a_{\varphi \pi} E_{t} \pi_{t+1}+a_{\varphi m c} E_{t} m c_{t+1}+a_{\varphi d} E_{t} d_{t+1}+a_{\varphi Y} \Delta y_{t}+\alpha_{p} \beta \pi^{\theta_{p}(1+\varepsilon)} E_{t} \varphi_{t+1}, \\
\psi_{t}=a_{\psi \pi} E_{t} \pi_{t+1}+a_{\psi Y} \Delta y_{t}+\alpha_{p} \beta \pi^{-1} E_{t} \psi_{t+1} .
\end{gathered}
$$

The variables $d_{t}$ and $s_{t}$ are measures of price dispersion and demand dispersion, respectively. As emphasized by Kurozumi and Van Zandweghe (2018), lags of the dispersion measures are endogenous state variables. Their laws of motion are given by:

$$
\begin{gathered}
d_{t}=a_{d} \pi_{t}+\rho_{d} d_{t-1} \\
s_{t}=a_{s}\left(\pi_{t}+d_{t}-d_{t-1}\right)+\alpha_{p} \pi^{\theta_{p}(1+\varepsilon)} s_{t-1} .
\end{gathered}
$$

With some further algebra, the GNKPC can be written as equation (2) in the text. The parameters $a_{\pi}, a_{\varphi \pi}, a_{\varphi \mathrm{mc}}, a_{\varphi \mathrm{d}}, a_{\varphi \mathrm{Y}}, a_{\psi \pi}, a_{\psi \mathrm{Y}}, a_{d^{p}}$ $\rho_{d} a_{s}, B, \gamma, \kappa_{1}, \kappa_{2}, \lambda, \lambda_{1}$, and $\lambda_{2}$ are nonlinear functions of the structural parameters. Furthermore, aggregate output is given by:

$$
y_{t}=n_{t}-\left(\frac{s}{s+\varepsilon}\right) s_{t},
$$

where $n_{t}$ denotes the labor input and the steady-state value $s$ is a nonlinear function of structural parameters.

To sharpen the intuition for the different results obtained with the two models, I write inflation in terms of infinite sums of the driving variables. The standard NKPC, denoted by equation (1) in Section II, can be rewritten to relate the change in inflation to the current and the discounted expected future real marginal costs as follows: 


$$
\Delta \pi_{t}=(1+\beta) \kappa \sum_{j=0}^{\infty} \beta^{j} m c_{t+j} .
$$

Thus, the change in inflation is determined solely by firms' current and expected future real marginal costs. Likewise, the GNKPC above can be rewritten to relate inflation to the current and discounted expected future real marginal costs, output growth (in the case of habit formation), price dispersions, and auxiliary variables, as follows:

$$
\pi_{t}=\sum_{j=0}^{\infty} \beta^{j} X_{t+j}
$$

where

$$
X_{t} \equiv \lambda_{1} m c_{t}+\lambda_{2} \Delta y_{t}+a_{\pi} d_{t}+\beta E_{t} d_{t+1}+d_{t-1}+\varphi_{t}+\psi_{t} .
$$

This demonstrates that inflation in the GNKPC is not determined solely by the current and discounted expected future real marginal costs but also by other variables. As a result, the model can account for the divergent post-recession paths of inflation and the real marginal cost. 


\section{Appendix B}

\section{Estimation Results}

This appendix presents the estimation results of the New Keynesian models with price indexation and without indexation.

\section{Model with price indexation}

The minimum distance estimation yields estimates for the structural parameters of the New Keynesian model with price indexation. Three parameters are fixed before estimation: the subjective discount factor, $\beta$, is set to 0.99 , and the parameters governing the elasticity of demand for differentiated goods and labor services, $\theta_{p}$ and $\theta_{w}$, are set equal to 10 . Table B-1 reports the estimated values of the remaining model parameters. The degree of price rigidity and the parameter governing the curvature of the goods demand curves are not identified individually, but the slope of the NKPC, $\kappa$, is estimated at 0.0038 . The estimated degree of wage rigidity is 0.5918 , implying wages remain unchanged for about 2.5 quarters on average.

The impulse responses of the estimated New Keynesian model with price indexation can be compared with the empirical impulse responses of the VAR (displayed in Chart 2). Chart B-1 plots the impulse responses of the short-term interest rate, the inflation rate, and the output gap (solid lines) along with their empirical counterparts (dashed lines). The impulse responses of the New Keynesian model capture the gradual rise in the short term interest rate and the hump-shaped responses of inflation and the output gap, although the latter two are less persistent than the impulse responses of the VAR.

\section{Model without indexation}

Table B-2 reports the results of the minimum distance estimation for the New Keynesian model without indexation. Four parameters are fixed before estimation: $\beta=0.99, \theta_{p}=\theta_{w}=10$, and the trend inflation rate, $\pi$, is set to 2.5 percent annually. The model without indexation allows identifying the degree of price rigidity $\left(\alpha_{p}\right)$ and the parameter that governs the curvature in demand curves $(\varepsilon)$. The estimated degree of price rigidity implies that prices change on 


\section{Table B-1}

Estimated Coefficients of the Model with Price Indexation

\begin{tabular}{l|l|c|c}
\hline \hline Coefficient & Description & Point estimate & Standard error \\
\hline$\kappa$ & Slope of the Phillips curve & 0.0038 & 0.0042 \\
$\alpha_{p}$ & Degree of price rigidity & - & - \\
$\alpha_{w}$ & Degree of wage rigidity & 0.5918 & 0.0001 \\
$\mathrm{~b}$ & Degree of habit persistence & 0.9382 & 0.0009 \\
$\sigma_{n}$ & Inverse labor supply elasticity & 1.7626 & 0.0001 \\
$\varepsilon$ & Curvature in demand curves & - & - \\
$\varphi_{\pi}$ & Policy response to inflation & 2.6856 & 0.0001 \\
$\varphi_{\mathrm{y}}$ & Policy response to output gap & 0.1227 & 0.0001 \\
$\varphi_{d y}$ & Policy response to output growth & 1.3638 & 0.0001 \\
$\rho_{I}$ & Policy response to first lag of interest rate & 1.0722 & 0.0022 \\
$\rho_{2}$ & Policy response to second lag of interest rate & -0.1309 & 0.0022 \\
\hline
\end{tabular}

Note: Standard errors are computed using the asymptotic delta method.

Sources: Bureau of Economic Analysis, Board of Governors of the Federal Reserve System, and author's calculations. All data sources accessed through Haver Analytics. 


\section{Chart B-1}

Impulse Responses of the Model with Price Indexation
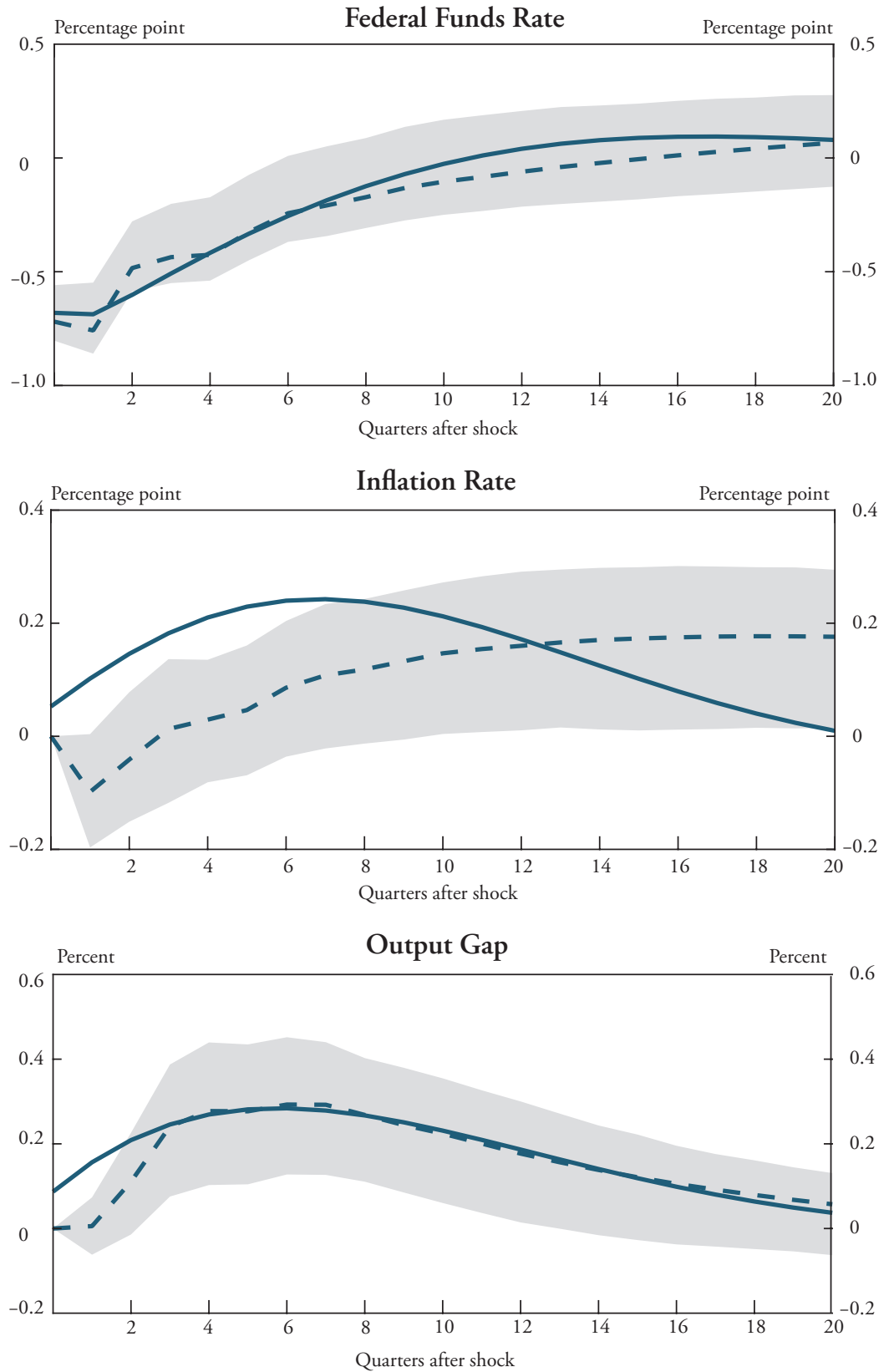

Sources: Bureau of Economic Analysis, Board of Governors of the Federal Reserve System, and author's calculations. All data sources accessed through Haver Analytics. 


\section{Table B-2}

Estimated Coefficients of the Model without Indexation

\begin{tabular}{l|l|c|c}
\hline \hline Coefficient & Description & Point estimate & Standard error \\
\hline$\alpha_{p}$ & Degree of price rigidity & 0.8448 & 0.0001 \\
$\alpha_{w}$ & Degree of wage rigidity & 0.3911 & 0.0001 \\
$\mathrm{~b}$ & Degree of habit persistence & 0.9290 & 0.0003 \\
$\sigma_{n}$ & Inverse labor supply elasticity & 1.7373 & 0.0001 \\
$\varepsilon$ & Degree of curvature in demand curves & -9.3737 & 0.0001 \\
$\varphi_{\pi}$ & Policy response to inflation & 2.9977 & 0.0001 \\
$\varphi_{y}$ & Policy response to output gap & 0.0011 & 0.0001 \\
$\varphi_{d y}$ & Policy response to output growth & 1.8633 & 0.0001 \\
$\rho_{I}$ & Policy response to first lag of interest rate & 1.1841 & 0.0007 \\
$\rho_{2}$ & Policy response to second lag of interest rate & -0.2490 & 0.0007 \\
\hline
\end{tabular}

Note: Standard errors are computed using the asymptotic delta method.

Sources: Bureau of Economic Analysis, Board of Governors of the Federal Reserve System, and author's calculations. All data sources accessed through Haver Analytics.

average about once per six quarters, which is a low frequency of price change similar to the estimate of Del Negro, Giannoni, and Schorfheide (2015). The degree of wage rigidity, at 0.3911 , is lower than for the model with price indexation, allowing for less smooth real marginal cost dynamics. The estimated value of the curvature parameter implies a curvature of $-\theta_{p} \varepsilon=93.7$, which exceeds micro estimates but is in line with the values used in other macro research. The estimated values of the remaining model parameters are in line with the values obtained for the model with price indexation. The estimated parameters imply that the slope of the generalized NKPC, $\kappa_{1}$, equals 0.0073 .

Chart B-2 plots the impulse responses of the short-term interest rate, the inflation rate, and the output gap generated by the estimated model without indexation (solid lines), along with the empirical impulse responses generated by the structural VAR (dashed lines). The impulse responses of this model once again capture the gradual rise in the short term interest rate and the hump-shaped responses of inflation and the output gap, although the latter two are less persistent than their empirical counterparts. 
Chart B-2

Impulse Responses of the Model without Indexation
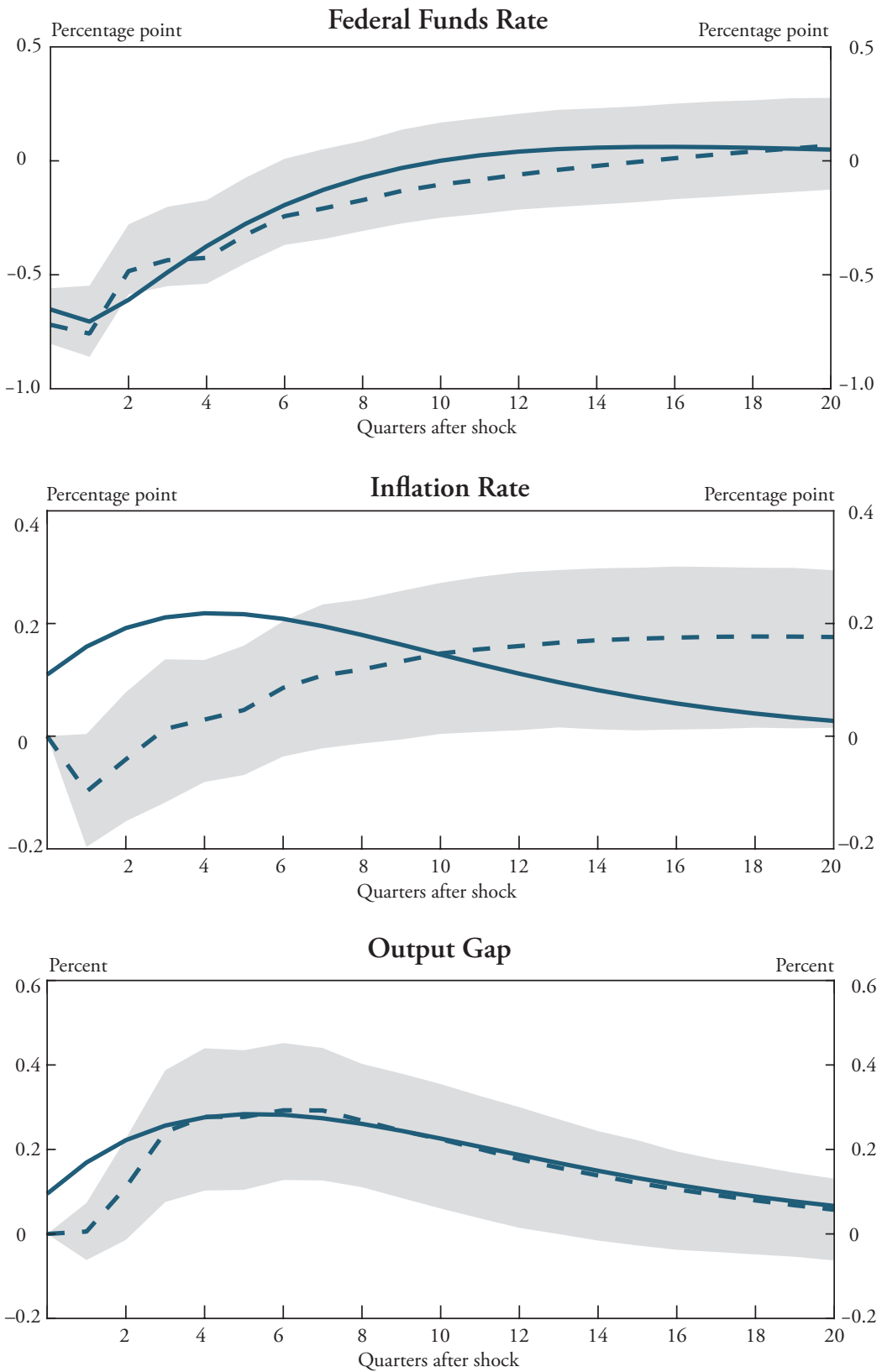

Sources: Bureau of Economic Analysis, Board of Governors of the Federal Reserve System, and author's calculations. All data sources accessed through Haver Analytics. 


\section{Endnotes}

${ }^{1}$ Empirical studies find that the association between inflation and unemployment-the so-called slope of the Phillips curve-strengthened in the 1960s, plateaued in the 1970s, and weakened again in the 1980s (Ball and Mazumder 2011; Matheson and Stavrev 2013; Blanchard 2016).

${ }^{2} \mathrm{Hall}$ (2011) spurred this research by arguing provocatively that "the dominant model of inflation embedded in practical macro models today... cannot explain the stabilization of inflation at positive rates in the presence of long-lasting slack." Other research has addressed the issue of the missing disinflation using statistical Phillips curve models, which pay less attention to microeconomic foundations, including Stock and Watson (2010), Gordon (2013), and the references in endnote 1.

${ }^{3} \mathrm{~A}$ linear trend has been removed from real unit labor costs in the chart to separate the cyclical fluctuations in the series from its secular downward trend. Elsby, Hobijn, and Şahin (2013) analyze the sources of the secular decline in real unit labor costs.

${ }^{4} \mathrm{Kim}$ (2018) finds that firms whose credit was curtailed in the recession actually lowered their prices and highlights firms' inventory management to explain the missing disinflation.

${ }^{5}$ In addition to higher interest rate spreads, Christiano, Eichenbaum, and Trabandt (2015) also emphasize the role of sluggish productivity growth in accounting for the small decline in inflation. Other research has examined the effect of the financial crisis on productivity growth; see, for example, Redmond and Van Zandweghe (2016).

'Lindé and Trabandt (2018) propose an explanation for the missing disinflation based on other nonlinearities.

${ }^{7}$ Consistently, the empirical evidence of Matheson and Stavrev (2013) and Blanchard (2016) indicates that inflation expectations have become steadily better anchored since the 1980 s.

${ }^{8}$ The flat Phillips curve reflects a high degree of nominal price rigidity. As firms expect to optimize their products' prices infrequently, their price-setting behavior becomes more attuned to expected future real marginal costs, which are greatly influenced by monetary policy, rather than to current marginal costs, which are heavily affected by shocks to the economy.

${ }^{9}$ The GNKPC is a variant of the model proposed by Kurozumi and Van Zandweghe (2018). It assumes a positive trend inflation rate, in line with positive average inflation observed in the United States. If the assumed trend inflation rate is zero, then both models coincide. Ascari and Sbordone (2014) review the literature related to the GNKPC, which is characterized by positive trend inflation and no price indexation. 
${ }^{10}$ The lags of inflation appear endogenously in this Phillips curve even though price-setting is purely forward-looking. Output growth only appears in the case of habit formation in consumption preferences.

${ }^{11}$ The inflation rate is the quarterly change in the logarithm of the GDP deflator, and the output gap is measured as one-half times the capacity utilization rate in the manufacturing sector, following Giordani (2004). The lag length of the VAR is four quarters. Monetary policy shocks are identified by assuming that only the federal funds rate responds contemporaneously to such a shock. Real unit labor costs are not used in the estimation. King and Watson (2012) point out challenges of using real unit labor costs to estimate Phillips curve models.

${ }^{12}$ The weighting matrix $W$ is a diagonal matrix that contains the inverse variances of the elements of $\hat{G}$, following Christiano, Eichenbaum, and Evans (2005), Giannoni and Woodford (2005), and Boivin and Giannoni (2006).

${ }^{13}$ Specifically, I assume the output gap declines an annualized 6.6 percent in the initial period (2008:Q4) and use the equilibrium decision rules of the estimated model to trace the dynamics of the output gap, the year-over-year inflation rate, and the real marginal cost.

${ }^{14}$ The model's forecast for the short-term interest rate remains positive, so the forecast of a small decline in inflation is not due to implausibly large policy accommodation in the model.

${ }^{15}$ More precisely, the ratio of RMSEs equals $0.548 / 0.636=0.86$ for inflation and $2.417 / 3.277=0.74$ for real unit labor costs.

${ }^{16}$ The model without indexation is a variant of the model of Kurozumi and Van Zandweghe (2018), who highlight the implications for inflation persistence of the interaction between positive trend inflation, staggered price setting, and the variable elasticity of demand. The model used in this article allows for habit formation in consumption preferences, from which Kurozumi and Van Zandweghe (2018) abstract. 


\section{References}

Ascari, Guido, and Argia M. Sbordone. 2014. "The Macroeconomics of Trend Inflation." Journal of Economic Literature, vol. 52, no. 3, pp. 679-739. Available at https://doi.org/10.1257/jel.52.3.679

Ball, Laurence, and Sandeep Mazumder. 2011. "Inflation Dynamics and the Great Recession,” Brookings Papers on Economic Activity, Spring, pp. 337-402. Available at https://doi.org/10.1353/eca.2011.0005

Bernanke, Ben S. 2010. "The Economic Outlook and Monetary Policy," Speech, Federal Reserve Bank of Kansas City Economic Symposium, Jackson Hole, Wyoming, August 27.

Bianchi, Francesco, and Leonardo Melosi. 2017. "Escaping the Great Recession." American Economic Review, vol. 107, no. 4, pp. 1030-1058. Available at https://doi.org/10.1257/aer.20160186

Blanchard, Olivier. 2016. "The Phillips Curve: Back to the 1960s.” American Economic Review: Papers and Proceedings, vol. 106, no. 5, pp. 31-34.

Boivin, Jean, and Marc P. Giannoni. 2006. "Has Monetary Policy Become More Effective?" Review of Economics and Statistics, vol. 88, no. 3, 445-462. Available at https://doi.org/10.1162/rest.88.3.445

Christiano, Lawrence J., Martin Eichenbaum, and Mathias Trabandt. 2015. "Understanding the Great Recession." American Economic Journal: Macroeconomics, vol. 7, no. 1, pp. 110-167. Available at https://doi.org/10.1257/ mac. 20140104

Christiano, Lawrence J., Martin Eichenbaum, and Charles L. Evans. 2005. "Nominal Rigidities and the Dynamic Effects of a Shock to Monetary Policy." Journal of Political Economy, vol. 113, no. 1, pp. 1-45.

Coibion, Olivier, and Yuriy Gorodnichenko. 2015. "Is the Phillips Curve Alive and Well after All? Inflation Expectations and the Missing Disinflation." American Economic Journal: Macroeconomics, vol. 7, no. 1, pp. 197-232. Available at https://doi.org/10.1257/mac.20130306

Del Negro, Marco, Marc P. Giannoni, and Frank Schorfheide. 2015. "Inflation in the Great Recession and New Keynesian Models." American Economic Journal: Macroeconomics, vol. 7, no. 1, pp. 168-196. Available at https://doi. org/10.1257/mac.20140097

Doser, Alexander, Ricardo Nunes, Nikhil Rao, and Viacheslav Sheremirov. 2018. "Inflation Expectations and Nonlinearities in the Phillips Curve." Federal Reserve Bank of Boston, Working paper.

Elsby, Michael W.L., Bart Hobijn, and Ayşegúl Şahin. 2013. "The Decline of the U.S. Labor Share.” Brookings Papers on Economic Activity, Fall 2013, pp. $1-63$.

Galí, Jordi, and Mark Gertler. 1999. "Inflation Dynamics: A Structural Econometric Analysis.” Journal of Monetary Economics, vol. 44, no. 2, pp. 195-222. Available at https://doi.org/10.1016/S0304-3932(99)00023-9

Giannoni, Marc P., and Michael Woodford. 2005. "Optimal Inflation Targeting Rules," in Ben S. Bernanke and Michael Woodford, eds., The Inflation-Targeting Debate, University of Chicago Press, Chicago, pp. 93-162. 
Gilchrist, Simon, Raphael Schoenle, Jae Sim, and Egon Zakrajšek. 2017. "Inflation Dynamics during the Financial Crisis." American Economic Review, vol. 107, no. 3, pp. 785-823. Available at https://doi.org/10.1257/aer.20150248

Giordani, Paolo. 2004. "An Alternative Explanation of the Price Puzzle." Journal of Monetary Economics, vol. 51, no. 6, pp. 1271-1296. Available at https://doi. org/10.1016/j.jmoneco.2003.09.006

Gordon, Robert J. 2013. "The Phillips Curve is Alive and Well: Inflation and the NAIRU During the Slow Recovery.” NBER working paper no. 19390.

Hall, Robert E. 2011. "The Long Slump.” American Economic Review, vol. 101, no. 2, pp. 431-469. Available at https://doi.org/10.1257/aer.101.2.431

King, Robert G., and Mark W. Watson. 2012. "Inflation and Unit Labor Cost." Journal of Money, Credit and Banking, vol. 44, no. S2, pp. 111-149. Available at https://doi.org/10.1111/j.1538-4616.2012.00555.x

Kim, Ryan. 2018. "The Effect of the Credit Crunch on Output Price Dynamics: The Corporate Inventory and Liquidity Management Channel." Mimeo.

Kimball, Miles S. 1995. "The Quantitative Analytics of the Basic Neomonetarist Model." Journal of Money, Credit and Banking, vol. 27, pp. 1241-1277.

Kurozumi, Takushi, and Willem Van Zandweghe. 2018. "Variable Elasticity Demand and Inflation Persistence." Federal Reserve Bank of Kansas City, Research Working Paper no. 16-09, April. Available at https://doi.org/10.18651/ RWP2016-09

Lindé, Jesper, and Mathias Trabandt. 2018. "Resolving the Missing Disinflation Puzzle," Working paper.

Matheson, Troy, and Emil Stavrev. 2013. "The Great Recession and the Inflation Puzzle,” Economics Letters, vol. 120, pp. 468-472.

Mineyama, Tomohide. 2018. "Downward Nominal Wage Rigidity and Inflation Dynamics during and after the Great Recession," Boston College, Working paper.

Phelps, Edmund S. 1968. "Money-Wage Dynamics and Labor-Market Equilibrium.” Journal of Political Economy, vol. 76, no. 4, pp. 678-711. Available at https://doi.org/10.1086/259438

Redmond, Michael, and Willem Van Zandweghe. 2016. “The Lasting Damage from the Financial Crisis to U.S. Productivity," Federal Reserve Bank of Kansas City, Economic Review, vol. 101, no. 1, pp. 39-64.

Stock, James H., and Mark W. Watson. 2010. "Modeling Inflation After the Crisis." Macroeconomic Challenges: The Decade Ahead, pp. 173-220. Proceedings of the Federal Reserve Bank of Kansas City Economic Policy Symposium, Jackson Hole, WY, August 26-28.

Woodford, Michael. 2003. Interest and Prices: Foundations of a Theory of Monetary Policy. Princeton: Princeton University Press. 